\title{
Contractualism and the Employment Contracts Act 199 Can They Deliver Equality for Women?
}

\author{
Margaret Wilson*
}

This article addresses the question whether employment equality for women is possible under the current provisions of the Employment Contracts Act, which rely on principles of contract to regulate the employment relationship. The article reviews inequality of women's lack of bargaining strength under the past and present employm regulatory frameworks, and discusses the relationship between women's political power contractual bargaining strength.

\section{Introduction}

The general purpose of this article is to explore the interrelationship between employme equality for women, citizenship rights, and the Employment Contracts Act 1991 (EC The specific purpose is to examine the role of the law in the construction and maintena of women's inequality in the workforce. The primary objective of the ECA is "to prom an efficient labour market". ${ }^{1}$ The legal means by which this objective is to be achie is through the concept of contract. The ECA is the last piece of a policy mosaic that designed to fundamentally reconstruct the basis of the constitutional relationship betw the state and that section of its citizens who sell their labour. The overall thrust of economic policy was to effect a similar change in all social, as well as econom relationships. The basis of this policy lies in the notion of contract. All relationships future are to be constructed in terms of contract. The rationale behind the employm policy was twofold. First it was argued that a market driven labour market policy wo bring economic benefit to New Zealand as a nation; and second, it would enhance individual freedom of those citizens who buy and sell labour. (The Treasury, 1984, 1987

It is argued in this article that the ECA changes the nature of the relationship between state and those citizens who sell their labour under a contract of employment. Wher prior to 1991 there was an assumption, or some may argue a "contract" , that the state a responsibility to ensure the individual was accorded equality of bargaining strength in determination of the terms of an employment contract, after the 1991 ECA the Nation

* Professor of Law, University of Waikato.

1 Employment Contracts Act 1991, Preamble to the Act.

2 The Treasury, (1984), Economic Management: (1987), Government Management, Wellington, Government Printer. 
overnment withdrew the state from that responsibility. The government had determined at the individual alone was responsible for their own bargaining strength when negotiating eir employment contract. This decision was reinforced by the removal of support from her state agencies, for example, the regulatory and enforcement role from the Department Labour, and the arbitration function from the Employment Court. This change in policy as legitimised through the enactment of the Employment Contracts Act.

is further argued in this article that women have been doubly disadvantaged under what as in effect a redrawing of the citizen-state "contract". Women have never been able to tain full and equal citizenship rights, because of the inclusion of what has been termed , Pateman (1988) "the sexual contract" in the construction of the institutions and rules that jvern the actions of individuals and their relationships with each other, and with the ate. ${ }^{3}$ The essence of the sexual contract is that the relationships between men and women e organised hierarchically, with men being accorded the dominant role and women the bordinate position. All institutions within society, including the employment relationship id the legal system that supports it, are imbued with this patriarchal practice and attitude.

\section{he sexual contract}

he disadvantage experienced by women because of the patriarchal nature of the sexual intract has been challenged by women in New Zealand since the colonisation. Since the :80s, women in New Zealand have campaigned for equal pay and equal employment pportunities (Lovell-Smith, 1993), ${ }^{4}$ which for the sake of brevity will be referred to as aployment equity. ${ }^{5}$ For women at the end of the nineteenth century, employment equity eant equal pay for equal work; the right to enter an occupation of their choice; the right be treated equally in terms of conditions of employment; and the right to advance within eir chosen occupation. In other words, women wanted to fully and equally participate ithin the paid workforce in such a way that enabled them as women, and not as honorary ales, to use their skills and abilities to the fullest extent.

is significant that the campaign for employment equity at that time was associated with e campaign for women's suffrage. The connection between full citizenship rights and onomic equality for women was clearly understood by the early feminists. They cognised that if women were to participate fully and equally within the workforce, they

Pateman, Carole (1988), The Sexual Contract, chapters $1 \& 2$ set out her argument that the sexual contract was institutionalised within the nation state's constitutional arrangement. The sexual contract is characterised by the patriarchal relationship that dominates all relationships between men and women.

$4 \quad$ Lovell-Smith, Margaret, (1992), The Woman Question:Writings by the Women Who Won the Vote, pp.105-150 contain a collection of writings by the early feminists on women's role, where the relationship between citizenship and economic equality is discussed.

The term employment equity was first formally used in Canada, and adopted by the Working Group on equal Employment Opportunities and Equal Pay in their Report, (1988), Towards Employment Equity, Wellington, Government Printer. 
needed to be part of the decision making that affected the workforce. This meant needed to make the laws that governed the employment relationship to ensure the reme of regulatory barriers to their full participation. They also needed to have, and be seen have, the social and economic status necessary to bargain equally when negotiating t individual conditions of employment.

To acquire this necessary social and economic status, women had to acquire full rights citizenship, which included not only the right to vote, but the right to stand for Parliame and then to fully participate, as an equal, in all aspects of political decision making. New Zealand, women did not achieve full legal citizenship until 1919, when the law changed to permit women to stand for Parliament. Up until that time, women lacked formal status to participate directly in political decision making. ${ }^{6}$ Without this form status, women could not be a full and equal party to, and participate in, the formation the institutions and rules on which civil society was founded. Pakeha women then cou not be a party to the Treaty of Waitangi or any government until 1919, because they lack sufficient citizenship status to be part of the institutions of government. Although wom could not be a party to the decisions that contributed to formation of the institutions rules that were to govern them, they were affected and bound by its terms.

It is important to note however, that although women lacked full political contractu capacity until 1919, the law conferred on them the capacity to enter an employmes contract, and a variety of other private law contracts. Although women had the leg capacity to enter a contract and be bound by its terms, their contractual negotiating capaci reflected the subordinate position women held within society generally. This subordina contractual status was the consequence of what Pateman $(1988)^{7}$ describes as the sexu contract being incorporated as an integral part of all civil, social and economic relationship The nature of the traditional sexual contract has ensured the dominance of men in decision making, including those decisions that affect the status of women as citizens. T dominance is evidenced today in the fact that only 16 percent of the members of Parliam are women, and only one woman is a full Cabinet Minister. Although the new elector system of mixed member proportional representation (MMP) was claimed to provi women with greater access to Parliament, this is unlikely because women must still compe within political parties that remain dominated by men and the values of patriarchy. ${ }^{8}$

6 The development of the rise of the theory and Practice of women's demand for a $m$ participatory democracy are discussed in Haywood, Bronwyn (1993), Participato Democracy: Questions Raised by Feminist Involvement with Theory and Practice, in C Helena and McLeay, Elizabeth, Women and Politics in New Zealand, Wellington: Victor University Press, pp.40-62.

Pateman, (1988), supra, pp.1-18.

For a discussion on the barriers facing women in representative politics see Mcle Elizabeth (1993), Women and the Problem of Parliamentary Representation: A Comparati Perspective, in Catt, Helena and Mcleay, Elisabeth, Women and Politics in New Zealan Wellington: Victoria University Press, pp.40-62. 
The fact that women have an unequal contractual bargaining position in both public and private sector contract formation has not been considered an impediment to their legal capacity to be a party to a contract. This is because the formal legal impediments have been removed. The most notorious legal disability inflicted on women was the common law rule that married women lacked legal capacity to enter contracts in their own right. The rationale for this limited contractual capacity was that, since a married woman could not own property in her own right, she had no means of settling her contracts (Holcombe, 1983). ${ }^{9}$ This legal disability was removed in New Zealand by the Married Womens Property Act 1884, but only after a struggle of 27 years by women in England to change their law. The enactment of this Act was an important victory for women who campaigned for full citizenship rights for women. It is interesting to note in this context that the arguments used by women at that time relied heavily on the concepts of freedom and equality that were central to nineteenth century liberalisation, as well as what was considered the radical concept of utilitarism advocated by Jeremy Bentham.

Although women have formal legal capacity to contract, this does not mean they enter contractual negotiations as equals. Women's contractual bargaining strength is determined not by legal status but by social and economic status. The law is part of the process of construction and maintenance of women's subordinate bargaining position. It is the fact nowever, that women do not make the decisions that affect their social and economic lives hat is the major determinant of their lack of bargaining strength. As Kahn-Fruend (1972) 1oted "Law is a technique for the regulation of social power." 10 Since women lack social jower, this is reflected in the laws that are made.

In the employment context, women's lack of bargaining strength also arises from the nature of the contract. The origins of the employment contract are found in the relationship of naster and servant. The employment relationship has never been one of equality. The relationship between the employer and the individual worker was described by KahnFreund (1972) as "...a relation between a bearer of power and one who is not a bearer of oower." 11 The power has always resided with the party employing the labour. The dominance of the employer in the employment contract was recognised by the common law. The employment contract was characterised by the common law as a special contract, not subject to the normal contractual principles. This is seen in some of the fundamental legal rinciples of the employment contract. For example, a major identifying characteristic of he employment contract is the fact of the employer's control of the employee's activities while employed (Wedderburn, 1986). ${ }^{12}$ It is also interesting to note that it was difficult to sbtain an injunction to enforce a term of the contract, because the courts considered the

$9 \quad$ See Holcombe, Lee (1983), Wives \& Property, Oxford, Martin Robertson for a full discussion of the campagin for married women to be given full rights to own property in their own right. She also places this struggle in the context of the campaign for women to be given full citizenship rights.

Kahn-Freund, Otto (1972), Labour and the Law, London, Stevens \& Sons, p.4.

ibid., p.8.

Wedderburn, Lord (1988), Worker and the Law, (3rd ed.), Penguin, pp.106-120. 
employment relationship a personal one of trust and confidence, which the law canno apply. Although the notion of trust and confidence had its origin in the master-servar nature of the employment contract, the Courts have adapted the notion to curren employment contracts, as has been seen recently in the Brighouse Ltd case (1994). ${ }^{13}$

\section{The role of the law}

Although an understanding of the gendered construction of sex roles lies in the complexity of the interrelationship of the economic, social and political factors that contribute to the inequality of women, the law has also played a central role in the construction anc maintenance of women's subordinate role in employment. In the New Zealand context, the common law has played a secondary role to statutory law. The inadequacies of th common law principles governing the employment relationship were apparent early in $\mathrm{Nev}$ Zealand's industrial history. The remedy for these inadequacies was seen as strengthening the bargaining position of employees through creating a viable trade union movement, tha could force the employer to the negotiating table. Since it was apparent that the employe had nothing to gain from voluntarily bargaining with a trade union, legislation was required to impose a duty on the employer to negotiate. Since legislation could only be enacted i Parliament, working people had to achieve full citizenship rights to be in a position control the legislative process.

It was therefore no accident that the 1889 electoral changes, that included the introduction of one man one vote, were closely followed by the enactment of the Industrial Conciliation and Arbitration Act (IC\&A Act) in 1894. Since women did not have full citizenship rights at that time, it is also no surprise that the terms of the traditional sexual contract were incorporated within the IC\&A statutory framework. Women's primary role was seen a being in the home and not in paid employment. This attitude was clearly seen in the Arbitration Court's determination that a living wage should support a married man, his wife and three children. While then the IC\&A system directly improved the position o working men, the beneficial effect for women was not so great.

Before a consideration of the impact of the law is undertaken, it is important to note that the law is not the only, or even the most important cause of discrimination against women in employment. The law, however, is an integral part of the perpetuation of the inequality of women. Its importance lies first in the legitimacy it confers on the actions of those with political power and influence. The authority of the state can be legitimately used to impose or enforce a particular set of behaviours, including discriminatory behaviours. For example, under both the IC\&A Act and the ECA, the subordinate negotiating position of women employees was incorporated within the provisions of those Acts, and thereby made lawful, This subordination is expressed through the omission of provisions that would compensate for women's lack of bargaining strength.

Secondly, the law's importance lies not only within the legitimacy it gives to specific actions incorporated in the provisions of a particular piece of legislation, but also in the 
legitimacy it gives to the legal institutions and their procedures and rules that are used in the administration of justice. Women have been, and remain, absent from positions of authority in the administration of justice. For example, New Zealand still has no Court of Appeal judge who is a woman. Also no woman has been appointed to the Employment Court, and only a minority of members of the Employment Tribunal are women. Women's employment experience has also been marginalised by the legal system. Employment experience is dichotomised into that of male employees, the norm experience, and that of women employees, the exceptional experience. It is norm experience that is incorporated within the general employment legislation.

Because the general legislation does not incorporate the women's experience, it has been necessary for women to constantly lobby for the enactment of new legislation to accommodate their interests. This struggle for legal change is one that has also been undertaken from a position of little political influence or power. It must be noted that in theory there is no reason why the general legislation could not have been interpreted in a non-discriminatory way. The traditional subordination of women that imbues the legal system has made such an interpretation impossible. The courts have required specific legislative direction to accord women equal rights. The most famous and extreme example of this approach was when the courts refused to interpret the word "persons" as including women for the purpose of giving women the right to vote (Sachs \& Wilson, 1978). ${ }^{14}$ A more recent example was the refusal of the Labour Court in the Clerical Workers Union case to interpret the Equal Pay Act to mean equal pay for work of equal value. ${ }^{15}$

Legal recognition for the employment rights of women does not always guarantee that an effective remedy is available. Sexual harassment is an example of a successful struggle by women to make their workplace a safe environment. The interpretation of the sexual harassment provisions by the Employment Tribunal and Employment Court has, however, effectively denied women a remedy under the ECA (Davis, 1994). ${ }^{16}$ If it was not for the existence of an alternative jurisdiction under the Human Rights Act 1977, women would be in a difficult position. The anti-discrimination provisions of the Human Rights Act 1978 provide a similar example of a legal right without an effective remedy. The law, and the legal process through which the remedy must be pursued, take no account of the subordinate position of women generally in society, and the effect this has on women's ability to assert their legal rights. Legal recognition alone, then, does not mean women have a legal remedy. In the case of child care however, which provides one of the major barriers to women equally participating within the workforce, the law has yet to recognise that inadequate provision of and access to child care is a discriminatory barrier to women entering the paid employment.

14

Sachs, Albie and Wilson, Joan Hoff (1978), Sexism and the Law: A Study of Male Beliefs and Judicial Bias, Oxford, Martin Robertson, pp.21-35. Wedderburn, Lord (1988), Worker and the Law, (3rd ed.), Penguin.

15

New Zealand Federated Clerical, Administrative and Related Workers Industrial Association of Workers v Farmers Trading Co. Ltd and Ors, (1986), ACJ 203.

Davis, Wendy (1994), A Feminist Perspective on Sexual Harassment in Employment Law in New Zealand, IRR Monograph No.3, Wellington. 
For a detailed understanding of the role of the law in perpetuating the inequality of women in paid employment in New Zealand, it is necessary to begin with an analysis of the IC\&A system, before the impact of the ECA is considered. Discrimination against women in paid employment did not begin with the ECA. The ECA is merely the latest variant of employment related legislation that incorporates the contractually subordinate role of women. The importance of the ECA however, lies not only in the fact that it is current legislation, but in that it starkly exposes the weakness of women's bargaining position in the negotiation of her the employment contract. All compensatory measures for women's inequality of bargaining strength that were incorporated within the IC\&A system, have been stripped away with the repeal of the Labour Relation Act 1987 (LRA). The reality of the extent of the deterioration in women's contractual ability under the ECA is seen through a contrast with their position under the IC\&A system. The purpose of this comparison is not to demonstrate that women were better positioned under the IC\&A. Both statutory frameworks discriminate against women. The purpose is to analyse the nature of the discrimination so women can develop their employment equity agenda so that it avoids the worst affects of past policies.

\section{The position of women under the IC\&A system}

While women have always lacked the reality of equality of bargaining position that is an essential part of the theory of contract, in the New Zealand context the effects of this inequality have been ameliorated by the provisions of the industrial conciliation and arbitration regulatory framework. The IC\&A system was developed by the Liberal government in the 1890s, and in particular by William Pember Reeves, the first Minister of Labour, as part of a programme of reform to remedy the effects of the economic and social poverty that had resulted from the previous years of economic depression (Sinclair, 1965). ${ }^{17}$ The Liberal's programme of reform was founded on the assumption that the state was responsible for the well being of its citizens, and should use its power and authority to create a society that provided the conditions for its citizens' economic and social security (Sutch, 1966). ${ }^{18}$ The expression of this policy in the employment sector was enacted in the IC\&A Act 1894.

The specific objective of the IC\&A system was to provide a procedure whereby industrial bargaining would produce an outcome that prevented strikes and lockouts. An essential part of achieving that objective was the institutionalisation of the trade union movement. It was essential because the legislation only provided a framework within which employers and employees were expected to negotiate their employment contracts. For these negotiations to produce a contract that reflected the interests of both employees and employers, the inequality of their bargaining strength had to be recognised. This recognition in the IC\&A system was through the creation and maintenance of a trade union

17 Sinclair, Keith (1965), William Pember Reeves: New Zealand Fabian, Oxford, Oxford University Press.

18 Sutch, W.B. (1966), The Quest for Security in New Zealand 1840-1966, Wellington, Oxford University Press. 
movement that could provide a better balance of bargaining strength. The system did introduce a new balance of power in the workplace from which all employees, including women employees, benefited. Women benefited however, within the constraints imposed by the traditional sexual contract that was incorporated within the provisions of the IC\&A system.

Central to the idea of equality of bargaining within the employment relationship was an active responsible state. There has always existed in New Zealand a fundamental difference of view on the role of the state. Traditionally the trade union movement and the Labour Party - the industrial and political wings of the labour movement - have supported such a role for the state. When the Labour party first became the government in 1935, its policies incorporated the concept of the active responsible state. The radical nature of the measures of the Labour government can be likened to an attempt to construct a new basis for the social "contract" between the state and the citizen. The nature of the state's new role was most apparent in the social and industrial legislation that was enacted at the time.

A central element of the first Labour government's reconstruction package was the 1936 Amendment to the IC\&A Act. The IC\&A Act was one of the legislative measures that survived beyond the Liberal government of the 1890s. The 1936 Amendment Act provided the main statutory vehicle for the first Labour government to rebuild the trade union movement, which had become weakened by the depression of the 1920s and 1930s. It had been weakened by the abolition of the statutory right to arbitration. The lack of this statutory support demonstrated the inability of trade unions to protect the interests of their members. Wages and conditions had quickly deteriorated during this period. The statutory measures used to increase the bargaining strength of trade unions included compulsory union membership, monopoly coverage for unions that registered, legal enforceability of registered awards and agreements, multi-employer coverage by awards, and institutions that provided compulsory arbitration, conciliation and mediation of industrial disputes (Woods, 1963). ${ }^{19}$

This statutory framework produced an industrial relation system that comprised a large number of trade unions and trade union members, and a three tier system of wage determination - national awards, local enterprise or industry agreements, and general wage determinations awarded by the Arbitration Court to ensure wages kept pace with the cost of living. It was also a representative system, through which individual employees relied on officials of their trade union to negotiate on their behalf wages and conditions of employment. The degree of involvement of individual members in this process varied from trade union to trade union, and occupation to occupation. The enforcement of the terms of the award or agreement was also undertaken by the trade union on behalf of the individual member. Overall then, the individual employee and employer did not directly meet to negotiate the terms of the employment contract. The IC\&A system did not prevent such an encounter, it just rendered it unnecessary. Under this system, the bargaining strength of the individual employee was enhanced by being part of a trade union. 
Although women were directly affected by the provisions of the IC\&A Act, they were only indirectly involved in the development of the policy behind the Act or its enactment. This lack of involvement was understandable in the 1890s. Women did not get the vote until 1893, and while there was some support from women for the Liberal policies in 1893, (Grimshaw, 1972) ${ }^{20}$ they were not the writers or developers of the Liberals' policies. The success of their campaign for women's suffrage was a necessary precondition for participation in the political decision making process. By 1935 women had not only the vote, but also the right to stand for election to Parliament. However it was not until 1933 that the first women was elected to Parliament. Women's experience and influence at the Parliamentary level was therefore limited at the time of the first Labour Government. Undoubtably women did participate through the Labour Party in the development of the social and industrial policies of the first Labour Government (Gordon, 1989), ${ }^{21}$ but their influence was not strong enough to prevent the incorporation of the traditional roles of men and women within the social and economic legislation.

In the 1930s, women lacked the institutional power and influence to change policy. Women were policy takers, and not policy makers. The traditional roles of the dominant male and the subordinate woman were therefore an integral part of the IC\&A statutory framework. The expression of this gendered approach to employment conditions was evidenced in some awards and agreements that provided for a male and a female wage rate for the same work. Other awards and agreements excluded women from particular types of work, or restricted their access to it. The rationale for the exclusion and restriction of women from some work was given as the need to protect them from occupations or surroundings "...likely to cause their physical, mental, or moral deterioration" (Select Committee Report, 1975). ${ }^{22}$ This protective attitude, although originally well meaning, served to institutionalise the subordination of women. It also protected men from the competition of women's cheaper labour.

The changes introduced by the first Labour Government did, however, provide women with some tools to start to challenge the dominance of men in industrial relations decision making. The unionisation of female occupations, such as clerical work and the service industry, after the 1936 Amendment to the IC\&A Act, not only improved the wages of women, but gave them the potential to control trade union organisations that could be used to enhance their bargaining strength in contract negotiations with employers. The road to economic equality and industrial strength proved to be a long one however. Wage increases were largely dependent on the trickle down theory of wage relativities, and the periodic general wage orders of the Arbitration Court. Achieving positions of power within trade union organisations, and then being able to change the agenda of claims to reflect the

20 Grimshaw, Patricia (1972), Women's Suffrage in New Zealand, Auckland, Auckland University Press and Oxford University Press.

21 Gordon, Liz (1989), A Place in the Sun: Women in the New Zealand Labour Party, unpublished paper, Social Sciences Research Fund.

Report of the Select Committee on Women's Rights, (1975), The Role of Women in New Zealand Society, Wellington, Government Printer, pp.103-104. 
specific needs of women employees, did not take place until the late 1980s (Sarr, 1992) ${ }^{23}$, (Hill, 1994) ${ }^{24}$. Their arrival in these positions coincided with the abolition of the IC\&A system and many of the trade unions of which they were officials.

The IC\&A system, therefore, had both beneficial and detrimental affects for women employees. It did give New Zealand women one of the smallest gaps between male and female wage rates in the industrial world (Hyman, 1993) ${ }^{25}$. It also locked women into a rigid and bureaucratic method of wage determination over which they had little control. The system also improved working conditions for women and provided them some representation through their unions in industrial decision making. At the same time, women had little influence over the agenda of claims or ability to include in awards and conditions terms that reflected the needs of their roles in the paid and unpaid workforce. Finally, the IC\&A system locked women into an industrial relations system that was designed to primarily serve the needs of male employees. To change this system, women needed to change the regulatory framework, which in turn required women to have the power to make legislation that reflected their needs.

\section{Women's power to change employment legislation}

The choice of methods available to women to change the regulatory framework was limited by their lack of political power. Legislation was enacted by Parliament. The policy on which the legislation was based was influenced by those who influenced the politicians. Politicians were influenced by their own ideas and values, and those of their political supporters. Bureaucrats also played an important gatekeeper role in the preparation of policy into the form required to proceed from ideology to policy to law. Until the 1980s women were absent from the critical positions of influence. They were not in Parliament in any numbers that could be effective, nor were they in the bureaucracy. Even in 1991, women comprised only 9.3 percent of the state sector managers (State Service Commission, $1992)^{26}$. Where women had the easiest access to political influence was through the use of their vote, which is a very indirect method of influence, and more directly through their involvement within the organisations on whom the politicians relied to obtain and retain power.

Sarr, Patricia (1992, Out of the Chorus: The Progress of Women in New Zealand Unions, Wellington, NZ Council of Trade Unions.

Hill, Linda (1994), Feminism and Unionism in New Zealand: Organising the Markets for Women's Work, unpublished Ph.D. thesis, University of Canterbury. Practice - Emperor with No Clothes?, New Zealand Journal of Industrial Relations, 18(1): 44-57. 
Women had always been reasonably effective lobbyists, as was evidenced by the suffrag campaign. Lobbyists however must be political opportunists, who are always ready with the appropriate self serving reaction to the decisions made by the politicians or the bureaucrats. If women wanted to make the decisions that would implement their agenda of employment equity, they had to be in the positions of power where the decisions were made. This meant they had to hold leadership positions in the trade unions, political parties, Parliament. Women's assault on the citadels of political power proceeded throughout the 1970s and 1980s with varying degrees of success (Wilson, 1992) ${ }^{27}$. It did produce legislation such as the Human Rights Act 1977, the Parental Leave and Employment Protection Act 1987, the inclusion of sexual harassment in the Labour Relations Act 1987 (repealed), and the Employment Contracts Act 1991, and briefly the Employment Equity Act 1990, which must have had one of the shortest legislative lives on record (Wilson, 1993) ${ }^{28}$, (Hill, 1993). ${ }^{29}$

The task confronting the women who wanted to transform women's role from one of subordination to one of equality in the employment relationship required them to work within male dominated institutions, and with the tools of those institutions to fundamentally change them. Trade union women had to work within the IC\&A system, with all its contradictions for women employees, while the political women had to work within a patriarchal political system. The tools of legal reform, as has been referred to earlier, were imbued with the same patriarchy. Women working for change were aware of the contradiction of their position, but had no choice but to work within the existing system if they wanted to change the law.

Although the primary objective of the strategy for employment equity was to change the law, and through it begin the process of change of managerial behaviour, there was also a secondary objective. It was to acquire knowledge, through accumulating direct experiences, of how power worked at that level. This was necessary knowledge to prepare for the next policy phase when the legislative reforms to the IC\&A system failed to deliver the outcomes sought by women employees. Even without the intervention of the ECA, it is unlikely the provisions of the Employment Equity Act would have produced the equality sought by women employees. Whether it is possible to transform the subordinate role of women to one of equality through a process of reform is a question that will not be answered in this article. The experience of women in the reform during this time will provide useful material for this continuing debate.

Wilson, Margaret (1992), Employment Equity Act 1990: A Case Study in Women's Political Influence 1984-90, in Deeks, John and Perry, Nick (eds), Controlling Interests: Business, the State and Society in New Zealand, Auckland: Auckland University Press, pp.113-131.

28 Wilson, Margaret (1993), The Making and Repeal of the Employment Equity Act: What Next?, Women's Studies Journal NZ, 9(2): 68-86.

29 Hill, Linda (1993), 100 Years of the Vote: 80 Percent of the Pay: The Politics of Pay Equity, Women's Studies Journal NZ, 9(2): 87-113. 


\section{Employment Contracts Act - general implications}

Although the advent of the ECA was predictable after the National Party won the 1990 election, the impact of the Act on employment relations was not so predictable. Within three years the practice of industrial relations has disappeared to be replaced by the negotiation of the employment contract. The relative ease with which this radical transformation took place must raise questions about the strength of the institutional roots of trade unionism in New Zealand. The dependency of trade unions on the regulatory framework underlined the reliance of the union movement on state support. The strength of trade unionism and the principles it advocated on behalf of employees, were directly linked to the strength of support of the state for those same principles. The dangers of this reliance and dependency on the state have been long discussed within New Zealand trade unionism (Roth, 1973) ${ }^{30}$. The benefits for a large number of employees of a compact between the trade union movement and the state have been undeniable however. Over the past hundred years the trade union movement has negotiated with a variety of governments and state institutions. Trade unionism had been accepted as a part of New Zealand's democratic system of government.

The institutionalised tripartism of industrial relations, that developed under the IC\&A system, was also assumed by many to be part of the social "contract" on which the society was founded. The IC\&A system was more than a mechanism for the peaceful settlement for industrial disputes, or even a method for distribution of wealth. It was the recognition of the right of those who sold their skills and their labour to another to effectively participate in the decisions that determined the price and work conditions for the labour. In the absence of a written constitution, the IC\&A statutory framework was the equivalent of what rights were held by citizens in their capacity as employees.

The constitutional implications of the repeal of the LRA and its replacement by the ECA have been little understood because of the construction of the employment relationship as a solely private relationship. The use of the law of contract to provide the new regulatory framework for employment relationships was intended to reinforce the private nature of the construction of the relationship. The intention to withdraw the state from responsibility for the outcomes that result from individual contractual bargaining is seen not only in the preamble to the Act, but also in the absence of any recognition in the Act of the inequality of bargaining strength between employees and employers. The intention not to create an equality of bargaining regime is made clear in section 57 of the Act that provides that the Court is to have no jurisdiction to provide any remedy for any employment contract under the law relating to unfair or unconscionable bargains. The section makes it clear the government's intention was to construct structural inequality of bargaining. As has been noted by many commentators, the ECA was the last statutory pillar that was necessary to 
complete the construction of a new society based on the principles of the market (Harbridge, 1993) ${ }^{31}$.

Apart from the ECA radically altering the general objective of the statutory framework, it supports this objective with specific provisions that are designed to cement in the new policy direction. These specific provisions include replacing national agreements with individual and enterprise contracts as the legal instruments regulating the employment relationship; according trade unions no preferred status in the employment contract (in fact trade unions are not mentioned by name in the legislation); replacing arbitration, conciliation, and mediation, with the formal legal process as the preferred method for settlement of disputes that arise under the employment contract; and placing responsibility on the individual employees for the content and enforcement of their employment contracts, except in respect of the area of personal grievances, which survive as a conceptual anomaly from the IC\&A system.

The fact that these legal provisions have substantially changed the practice of employment relations is evidenced by the decrease in the number of trade unions from 259 in 1985 to 67 in 1993; a decrease in the number of trade union members from 683,006 in 1985 to 409,112 in 1992 (Harbridge and Hince, 1994) ${ }^{32}$; and a collapse in the number of employees covered by collectively bargained agreements of between 40 to 50 percent in a two year period (Harbridge, Honeybone and Kiely, 1994) ${ }^{33}$. It is acknowledged that a full understanding of the significance of this data requires a more detailed analysis than is possible in this article. The general point to be made in this context is that the ECA has had a major impact on the practice of employment relations. Whether these structural changes to the employment relationship have also resulted in a deterioration in employment conditions for individual women employees will now be considered.

\section{Employment Contracts Act - implications for women}

It has been argued by the supporters of the ECA that the withdrawal of state support and reliance on individual contracting will benefit employees. Whether women employees have benefited from the ECA regime is doubtful on the available evidence. There are two ways to assess the effect of the ECA on the employment interests of women. The first is to

31

Harbridge, Raymond (ed.) (1993), Employment Contracts: New Zealand Experiences, Wellington, Victoria University Press.

Harbridge, Raymond and Hince, Kevin (1994), A Sourcebook of New Zealand Trade Unions and Employee Organisations, Industrial Relations Centre, Victoria University of Wellington.

Harbridge, Raymond Honeybone, Anthony Kiely, Peter (1994), Employment Contracts: Bargaining Trends \& Employment Law Update: 1993/94, Industrial Relations Centre, Victoria University of Wellington. 
compare the wages and conditions of women before and after the enactment of the ECA. ${ }^{34}$ The second method of assessment is to look at the underlying causes of women's employment inequality to establish whether the ECA has redressed the detrimental effects of those causes. This involves not only an examination of women's social and economic position, but whether the concept of contract is inherently capable of delivering equality for women.

It must be noted before this assessment is undertaken, that the ECA has been in force for only three years. It may be argued then that it is too early to make a final judgment of the effects of the Act. It may equally be argued that, if the ECA itself specifies a process of contract formation that is inherently inequitable to women because of their subordinate bargaining position, then no matter how long the Act is in force in its current form, it will produce an inequitable outcome for women. It must further be noted that any discussion of women is inhibited by the lack of relevant data. This is another manifestation of the subordinate role women are deemed to have within our society.

The ECA poses particular problems in this respect because the privacy of information relating to the employment contract is an integral part of constructing employment relations as a purely private relationship. For example, one of the major inhibitors of information is section 24 of the ECA, which provides that only collective contracts that bind 20 or more employees are required to be lodged with the Secretary of Labour. Since most women are not likely to be covered by such agreements, it is very difficult to establish the true nature of their employment contracts. Barriers to information are another form of exercise of power and control that detrimentally affects women in paid employment.

The available data on the impact of the ECA on women has been analysed by Hammond and Harbridge $(1993)^{35}$ and does not need to be repeated in detail in this article. The conclusion of their study was "... that the Employment Contracts Act does not offer any advantage to women workers, and that, in fact, it has clearly disadvantaged women workers" (Hammond and Harbridge, 1993: 28) ${ }^{36}$. This conclusion was based on data that showed men are more likely to receive larger increases than women; that men are more likely to attract penal and overtime rates, while many women have lost these allowances; and men were more likely to receive productivity based payments. The study did find, however, that women in collective agreements retained better leave entitlements. Although this study was useful, the authors themselves note that they had access to collective contracts only, in which women were likely to have retained more favourable conditions Beyond the Barriers, Wellington, National Advisory Council on the Employment of Women. The most comprehensive assessment of the data available on the impact of the ECA is found in Hammond, Suzanne and Harbridge, Raymond (1993), The Impact of the Employment Contracts Act on Women at Work, New Zealand Journal of Industrial Relations, 18(1): 1530. 
than most women employees covered by individual contracts (Hammond and Harbridge, 1993: 28-29). ${ }^{37}$

The Hammond and Harbridge findings are consistent with a statutory framework that reinforces the underlying causes of women's employment inequality. The provisions of the Act do nothing to break down the segregation of the labour market in male and female occupations. Nor does the Act do anything to redress the undervaluation of women's skills compared with male occupational skills. The supporters of the Act would argue that the legislation itself was never intended to achieve these outcomes, but that an individual woman could negotiate into her contract a more favourable payment for her skills. This was the approach taken by the National Party Working Party on Equity in Employment. ${ }^{38}$

This Group stated that it was not persuaded that there was a link between equal employment opportunities and pay equity. It recommended that while some form of legislative intervention was appropriate for equal employment opportunities, the interests of women were not served by "perpetuating the artificiality that imposed arbitrary settlements effect" (Report of the Working Group, 1991: 12). ${ }^{39}$ This approach was endorsed by the National government that considered "...progress towards an equal employment opportunities environment will be most effectively achieved where employers are closely involved in the voluntary promotion of progressive EEO management practices" (Joint Press Release, 1991). ${ }^{40}$ The ECA reflects this voluntary approach and the result has been that employment equity is even further away for many women, because even some of the gains of the past have now been lost.

The ECA also does little to assist women with the demands of paid and unpaid work. It was argued by the advocates of the Act that it would give women more flexibility to organise their time to accommodate the two roles. The dangers for women in this so-called flexibility have been discussed by Sayers (1993). ${ }^{41}$ In this context, it is important to reinforce the point that this flexibility is frequently contractually imposed on women, who if they want a job must accept the terms as offered to them. For example, a recent survey on part-time work found that 28 percent of the women surveyed wanted more hours of paid work (Davidson and Bray, 1994: 13-20). ${ }^{42}$ Also a flexible work arrangement that accommodates the double role not only exaserbates the stress on women, it cements into

ibid., Hammond and Harbridge, pp.28-29.

Report of the Working Group on Equity in Employment, (1991).

ibid., p.12.

Joint Press Release of Hon. W.B. Birch, Minister of Labour and Hon. Jenny Shipley, Minister of Women's Affairs, 18 July 1991.

Sayers, Janet (1993), Women, the Employment Contracts Act and Labour Flexibility. In Harbridge, Raymond (ed.), Employment Contracts: New Zealand Experiences, Wellington, Victoria University Press, pp.210-223.

Davidson, Carl and Bray, Marianne (1994), Women \& Part-Time Work in New Zealand, Christchurch: NZ Institute for Social Science Research and Development Ltd, pp.13-20. 
the new employment regulatory framework the subordinate role of women that arises from the traditional sexual contract. It is another example of how women must fit into male work norms, rather than redesigning work practices that incorporate on an equal basis the demands of unpaid domestic work.

Finally, the ECA does nothing to rectify the inequality of bargaining strength between women employees and their employers. The Act is founded on the assumption that they are equals. The fact that employees and employers are not equals when negotiating their employment contract has even been recognised by the common law, as mentioned earlier in the article. Nothing has changed in the reality of women employees working lives to alter this judgment of a contractual inequality. Women are still ghettoised in the workforce in occupations that are distinguished by their low skill and low pay. The trend of women into positions of authority is painfully slow (Department of Statistics, 1993: 79-104). ${ }^{43}$

Since contractual inequality is inherent within the employment relationship, if equality of bargaining is to be achieved, then specific provision must be made in the law to rectify the imbalance. The IC\&A system was one attempt to achieve a balance. Another method is the enforcement by the Employment Court and the Court of Appeal of the common law implied duty on the employers to conduct themselves in a manner calculated to enhance the confidence and trust between the employee and employer as was decided in the Brighouse Ltd case. $^{44}$ If this approach of the Courts is to benefit women, the implied duty would need to extend to the duty to bargain fairly. If this was done, then the bargaining strength of women would be improved. Extending the duty of trust and confidence to a duty to bargain fairly would not, however, necessarily benefit women, because what is fair is likely to be interpreted objectively. This would mean that what is fair would be assessed as what is fair for a male employee, whose work experience is the norm experience. It would be essential, therefore, that fairness would include an acknowledgment by the Courts that women's subordinate contractual position results from the terms of the traditional sexual contract.

While the ECA remains in force, a reassessment of the employer's common law contractual duties may provide some limited relief for individual women. Since women's employment inequality is structural and systemic, an effective remedy must also be structural and systemic. The common law provides individuals with individual remedies. The only institution within society with the authority to provide such a structural remedy is government. If government was to use its authority to remedy women's employment equality, it would need to do more than enact more legislation, though legislation would provide the necessary legitimisation for the employment equity policy. The government would also need to reallocate the resources of the state to redress the social inequality experienced by women. Matters such as adequate child care, paid maternity leave, greater incentives to enable the easier transition from state benefit to employment, and employment equity training would all need to be funded. Such a policy change in funding is unlikely because there is no incentive for the government to provide the conditions for women's 
equality. In fact the current policy is to a large extent dependent on women retaining thei current subordinate role.

\section{Conclusion}

This article has attempted to identify the nature of the discrimination against women tha is currently enacted in the ECA. Apart from the economic discriminatory nature of the legislation, it is also anti-democratic because it denies women the means to be able to fully participate in the process that determines their employment rights and obligations. It must be concluded that the current provisions of the ECA make it unlikely that the substantive employment position of women will ever be improved. It is conceded that it may be possible to enhance the contractual position of individual women if notions of fairness, that are judged according to the position and needs of women, are incorporated into the legislation, or through the implied duty of trust and confidence.

While such a provision would be welcomed, it would do little to redress the underlying needs of women to reform the whole structural and systemic nature of their inequality. In the absence of any possibility of legislative change before the next election, the only hope for women who pursue a legal remedy is through encouraging the Courts to use their common law jurisdiction to try and restore some element of democracy into the negotiation of employment contracts, whether they be individual or collective contacts.

\section{References}

Davidson, Carl and Bray, Marianne (1994), Women \& Part-Time Work in New Zealand, Christchurch: NZ Institute for Social Science Research and Development Ltd.

Davis, Wendy (1994), A Feminist Perspective on Sexual Harassment in Employment Law In New Zealand, IRR Monograph No.3, Wellington.

Gordon, Liz (1989), A Place in the Sun: Women in the New Zealand Labour Party, unpublished paper, Social Sciences Research Fund.

Grimshaw, Patricia (1972), Women's Suffrage in New Zealand, Auckland, Auckland University Press and Oxford University Press.

Hammond, Suzanne and Harbridge, Raymond (1993), The Impact of the Employment Contracts Act on Women at Work, New Zealand Journal of Industrial Relations, 18(1): 1530.

Harbridge, Raymond and Hince, Kevin (1994), A Sourcebook of New Zealand Trade Unions and Employee Organisations, Industrial Relations Centre, Victoria University of Wellington. 
Harbridge, Raymond Honeybone, Anthony Kiely, Peter (1994), Employment Contracts: Bargaining Trends \& Employment Law Update: 1993/94, Industrial Relations Centre, Victoria University of Wellington.

Harbridge, Raymond (ed.) (1993), Employment Contracts: New Zealand Experiences, Wellington, Victoria University Press.

Haywood, Bronwyn (1993), Participatory Democracy: Questions Raised by Feminist Involvement with Theory and Practice. In Catt, Helena and McLeay, Elizabeth, Women and Politics in New Zealand, Wellington, Victoria University Press, 40-62.

Hill, Linda (1994), Feminism and Unionism in New Zealand: Organising the Markets for Women's Work, unpublished Ph.D. thesis, University of Canterbury.

Hill, Linda (1993), 100 Years of the Vote: 80 Percent of the Pay: The Politics of Pay Equity, Women's Studies Journal NZ, 9(2): 87-113.

Holcombe, Lee (1983), Wives \& Property, Oxford, Matin Robertson.

Hyman, Prue (1993), Equal Pay for Women After the Equal Pay Act: Legislation and Practice - Emperor With No Clothes?, New Zealand Journal of Industrial Relations, 18(1): 44-57.

Kahn-Freund, Otto (1972), Labour and the Law, London, Stevens \& Sons.

Mcleay, Elizabeth (1993), Women and the Problem of Parliamentary Representation: A Comparative Perspective. In Catt, Helena and Mcleay, Elisabeth, Women and Politics in New Zealand, Wellington, Victoria University Press, 40-62.

Pateman, Carole (1988), The Sexual Contract, Oxford, Polity Press.

Lovell-Smith, Margaret (1992), The Women Question:Writings by the Women Who Won the Vote, Auckland, New Women's Press.

NACEW, (1990), Beyond the Barriers, Wellington, National Advisory Council on the Employment of Women.

Report of the Select Committee on Women's Rights, (1975), The Role of Women in New Zealand Society, Wellington, Government Printer, 103-104.

Roth, H. (1973), Trade Unions in New Zealand: Past and Present, Auckland, Reed Educational.

Sachs, Albie and Wilson, Joan Hoff (1978), Sexism and the Law: A Study of Male Beliefs and Judicial Bias, Oxford, Martin Robinson. 
Sarr, Patricia (1992), Out of the Chorus: The Progress of Women in New Zealand Unions Wellington, NZ Council of Trade Unions.

Statistics New Zealand, (1993), All About Women in New Zealand, Wellington: Statistic New Zealand.

Sayers, Janet (1993), Women, the Employment Contracts Act and Labour Flexibility. I Harbridge, Raymond (ed.), Employment Contracts: New Zealand Experiences, Wellington Victoria University Press

Sinclair, Keith (1965), William Pember Reeves: New Zealand Fabian, Oxford, Oxford University Press.

State Services Commission (1992), Equal Employment Opportunities: Progress in the Public Service as at June 1991, Wellington.

Sutch, W.B. (1966), The Quest for Security in New Zealand 1840-1966, Wellington, Oxford University Press.

The Treasury (1984), Economic Management, Wellington, Government Printer.

The Treasury (1987), Government Management, Wellington, Government Printer.

Wedderburn, Lord (1988), Worker and the Law, (3rd ed.), Penguin.

Wilson, Margaret (1993), The Making and Repeal of the Employment Equity Act: What Next?, Women's Studies Journal NZ, 9(2): 68-86.

Wilson, Margaret (1992), Employment Equity Act 1990: A Case Study in Women's Political Influence 1984-90. Chapter in Deeks, John and Perry, Nick (eds), Controlling Interests: Business, the State and Society in New Zealand, Auckland, Auckland University Press.

Wilson, Margaret (1988), Towards Employment Equity: Report of the Working Group on Equal Employment Opportunities and Equal Pay, Wellington, Government Printer.

Woods, N.S. (1963), Industrial Conciliation and Arbitration in New Zealand, Wellington, Government Printer. 